\title{
TOWARDS AN UNDERSTANDING OF THE CRISIS IN FRENCH EDUCATION*
}

\author{
L. Shelton Huettig \\ University of Kansas
}

At the doorstep of a second industrial revolution, characterized by increasing automation and a more extensive use of computers, France is suffering a shift in the division of labor. An ever increasing percentage of the active population is employed in service occupations and a diminishing percentage in industry. The transition has stimulated an overall economic expansion and a rising standard of living which is reflected in increased consumption of material goods as well as services. All this points toward an evolution which has been observed in the United States during the last decade, where family expenditures are more and more oriented towards services.

The first phase of industrialization, which lasted until World War I, brought with it an occupational organization that essentially mirrored the steps of technical development. It utilized unskilled manual workers, skilled workers, and commercial and clerical personnel. "The social prestige and income of these groups reflected more or less closely their importance for production; and their training models, at least in the two higher groups, were those of preindustrial society-the merchant and the artisan."1

The introduction of semi-automatic machinery for mass production has created a new group of semi-skilled workers with a wide range of skills and training. The distinction between unskilled and skilled workers is no longer clear. "Furthermore, the shift in emphasis from immediate output to previous planning, as well as the increasing specialization of administration and distribution, have created a stratum of specially trained technical employees."2 The old division of labor is gradually disappearing.

With wider levels of automation, the worker performs the tasks of a technician--regulation, supervision, and repair. He is no longer tied to his machine but must perform varied tasks, many of which require technical skill. This changeover requires extensive retraining

*This manuscript was written during the summer of 1968 , and it is advised that the interested reader consult sources about recent developments in the French educational system. 
and relocation of the work force. H. Schelsky has pointed out that this new emphasis confronts education with many problems, and he enumerates several steps to resolve them. Individuals must be taught "...to apply technical means as such." An emphasis should be placed upon "plasticity and interchangeability of occupations." This flexibility should extend well up the ladder in "...industrial bureaucracies--from apprentice to technician and engineer."3

In American industry much of this has been accomplished and is continuing to develop. On the level of industrial organization and management, "flexibility" has become the byword. As Jean-Jacques Servan-Schrieber points out in "The American Challenge," this is America's most potent challenge to the European economy. If Europe does not take advantage of the opportunities offered by the Common Market, as the Americans have done they will find themselves economically dominated by U. S. business. 4

These rapid transformations in the modern world necessitate a profound change in methods of education. In the past, the role of the school in France was to give the pupils a limited number of basic elements (reading, writing, and calculating) to enable them to insert themselves satisfactorily into industry. At the secondary and higher levels of education--to which only children of the higher social classes had access, the training was directed toward "honnetes hommes" (in the sense of the seventeenth century man who obtained a cultural background with the end of conducting himself well in "society," rather than as members of the free professions.

Today, however, with the extraordinary university expansion resulting from "social demand" and the needs of a growing economy, we see various power groups--State (Administration), business, industry, and students, etc.--advocating a more professionally oriented education which would give the individual the best professional qualifications. At the same time, the professional qualification must be accompanied by a development of culture sufficient not only to enable the individual to adapt himself to rapid changes in his profession but also to a society in which government is based upon the premise that each individual is participating in both the production and the consumption of all goods.

France, in confronting these new elements, has remained static in its educational methods and structures, and this is the basis of much of student unrest today.

Ministerial committees charged with examination and elaboration of projects for educational reform have multiplied over the last ten years; in professorial and student circles as well as in the nation in general, positions are taken in favor of or against proposed reforms, the necessary of which is denied by no one. Education has been the subject of passionate political and ideological debates in which too 
often the projects for reform have been judged in terms of the past rather than in terms of the future.

\section{The Quantitative Revolution}

Meanwhile, education has undergone a quantitative revolution posing serious material and financial problems to students, professors and the government. "In less than fifteen years (1955-1970) the student population will approximately have doubled."

This increase in the number of students enrolled in universities derives from many different sources, several of which are considered here. The increase at the level of higher education which was evident from the early 1950's is not due solely to the increase of the birthrate which occurred in Europe at the close of the Second World War. The expansion was stimulated by a profound change in social demand for prolonged education, which showed a change in family attitudes toward secondary and higher education. First middle-class, then lower-class families tended to model their customs after those of the higher classes. W. R. Fraser pointed out:

The rapid rise in the post-war birth-rate accounts for some of this "explosion," but that increase is only $40 \%$ upon the pre-war figure. Primary school enrollments reflect this increase fairly exactly. The greater increase in secondary school pupils can only be accounted for by the trend to stay longer in school, and by the sociologically significant change in the percentage of secondary pupils being drawn from the lower-middle and working classes. Whereas in 1953 the Institut National des Etudes Demographiques estimated that $90 \%$ of upper professional class children, $60 \%$ of clerical class children and $19 \%$ of working class children entered a secondary school, a repeat sample investigation made by the Institut in 1962 puts these percentages at $92 \%, 84 \%$, and $42 \%$ respectively. 6

The granting of financial aid by the government to needy students has been a factor in augmenting the enrollment in France. Here, factors such as age, financial situation of the family, and type of studies are taken into consideration. The latter of these has been highly criticized for its tendency to direct students into areas that give higher aid but are contrary to their wishes.

A third factor which accounts for the expansion of higher education in France is the various governmental and university measures to open the university by changing the admission requirements. Latin and Greek, of which four years of the former and two of the latter were once required, have been limited in their scope. Modern languages have been added as an avenue to higher studies. This issue has caused a great controversy; as Robert Ulich remarks: 
For up to the very present the emphasis on the classics has gone hand in hand with a rigid separation of the secondary schools, destined to lead the elite of the nation to the university, from the schools for the common man. Every change in the school program, from the humanist-historical toward the scientific-technical curriculum, called into the arena the defenders of an aristocratic tradition against the advocates of democracy, the right against the left. 7

Only those students who were enrolled in the classical sections in secondary school could go on to the faculties offering professional training of the highest prestige (law, medicine, pharmacy, letters and philosophy, etc.) after they had obtained their Baccalaureat degree.

The last factor of significance with respect to the increase of the number of students over the last fifteen years is greater enrollment of female students. This phenomenon could be explained by the fact that many professions, previously reserved for male graduates, are now being opened to women.

\section{Centralization and Its Effects}

This quantitative revolution has affected the structure of higher education in France. The significance of the increase can only be understood when one observes that the legal structures of university education remain largely the same as those of the 19th century. When new universities have been built, plans were taken from the older universities.

Public education in France is highly centralized. The Baccalaureat examination is given on the same day at the same hour throughout the whole of France. The structure in the secondary schools as well as the universities is rigidly standardized by the central Ministry of Education and has been the same since the time of Napoleon. Decisions are made by the central administration without any true participation by the units of education (universities, faculties, and various institutes) and this, without consulting the core of teachers under 1 ts jurisdiction. In turn, the professors constitute a sovereign oligarchy concerning the co-option of its members, the form and the contents of education, and the granting of positions: assistantships are given by individual professors who then relinquish only a small number of their prerogatives.

Last of all, the student at the bottom of the hierarchy, does not participate in decisions at any of these levels. Accordingly, the institution of education, embedded in this hierarchy, has become more and more distant and strange in the eyes of its clientele. 
Coming from lower social strata many of the students now entering universities find their cultural background inadequate for academic work. The academic authorities elaborate the programs of study as they were done early this century and impose them upon students who have no way of influencing them, but whose fates are thereby determined. One of the criteria employed in organizing these programs is the concept that children coming from different social and geographic milieu are "interchangeable," that is, intelligence is distributed at the moment of birth without any distinction of class, and that children of any class have the same chance to acquire knowledge up to the highest level. Therefore, a high degree of uniformity exists within the educational system.

If a student were to attend any one of the public secondary schools, he would be submitted to the same structure. The secondary school student upon graduation finds that he has a limited choice of higher educational institutions. Apart from the "Grandes Ecoles," which he can enter only after highly selective testing that requires several years of preparation, there is very little difference in terms of prestige between the universities. The only distinction that is drawn is that between the university and the technical institution (which is in fact counted as an institute of higher learning). This encourages the student to direct. his attention toward the university. Once there, it is impossible for him to change his department or school without loosing much of the work that he had done previosly. Most students who change their initial choices do so as the result of a failure. Thus, the system orients through failure.

\section{Disparity Between Student Needs and the Educational System}

The relatively high percentage of failures at examinations and the high number of students lagging behind in comparison with the normal period of study in the universities is a factor in the crisis that French education is facing today. Dr. Otto Feinstein states that, "with respect to faculties, one can reasonably claim that the $57 \%$ success rate [in exams] is too high, as indeed, this percentage includes the famous 'Grandes Ecoles' where success rates amount up to 99.9 or $100 \%$." 8 The reaction of the students in Paris during the "May Revolution" of 1968 was to call for a boycott of the June exams to draw attention to the inadequacy of the system.

To eliminate this high rate of failure it has been proposed by a group of French educators to impose a system of selection on incoming students (to supplement the Baccalaureat, which now gives automatic admission). But this has met strong opposition from students and professors who feel that selection will be made on the basis of the number of professors and rooms that are available instead of intellectual criteria. And, to decide what intellectual criteria to follow would create a great deal of tension. 
"Democratization of education" has been one of the foremost demands made by groups agitating for reform in France. Financial aid has not kept pace with the expanding number of students wishing to pursue higher education. Students from the lower classes have not been given sufficient opportunity to take part in higher education. The means available to these students are limited once they reach the university; there is a lack of good libraries, of study halls, etc. 9

Students attend a university which in its basic organization is still that of the last century; and as such created for an elite which received there the scientific instruction necessary to practice a free profession or to be oriented toward research. These were prestigeful occupations but one had to be well to do in order to engage in long and expensive studies and even then one was not sure of gaining enough to live on. But a great number of students who attend universities today are not asking these goals of their university education. Few are interested in research; many are asking from their higher education that it grant them the possibility of practicing a profession that will support them; others are demanding that the degrees conferred upon them enable them to compete for civil service jobs. There exists a great gap between what the university is giving and what the students and the economy are demanding.

This gap manifests itself in the incapacity of university graduates to adapt themselves to the tasks of the modern world and the fact that many of them are unwilling to integrate themselves into the status quo of society. Students who graduate with a degree in business are very poorly adapted to the needs of modern business. This is due to poor orientation, a curriculum that is highly theoretical and outdated, and the social confinement of students while attending the university. In short, they all must be extensively retrained when they join a company. In writing about the recent student revolt in France, Frederic Gaupen and Guy. Herzlich state:

The idea that they will be inescapably "absorbed" by the system, due simply to their technical competence and their title, is insupportable to many. "Even the most radical among us will not be able to escape this absorption," affirms one of them.

This reaction is particularly clear with the students in sociology and psychology who for the most part are called to work in employment agencies or do market research. But it can also be seen with the literary students: "What will we teach and how?"10 
The students of today regard the relation between themselves and professors as "reproducing that of the father and the child'. The system of instruction, succeeding family domination, leads to the formation of 'obedient individuals and passive officials." 11 In general, there is no opportunity for discussion between student and professor. As Jean Block-Michel has noted, "a professor of psychology has to lecture to 4,000 students"12 at the University of Paris' Nanterre complex, and this is not uncommon. Pedagogy is strongly entrenched in large lecture halls where what the professor says is expected to be noted almost verbatim and parroted back on exams.

Without any doubt, the teachers want to participate directly in progress, but they want just as much, or even more, to guard traditions which have proved successful. "Each of these two opposed tendencies is in turn dominated and doninating. Thus are explained the fragmentary measures, the tentative procedures and the oscillations which for almost 200 years have marked the history of education."13 Here one must realize that the centralization of French education plays an important role in this tradition. John Forster points out that:

With any large scale organization there is a tendency to rationalize the organizational activities. In teaching--which, in the final analysis, is a highly personal relation--there is a need to be constantly alert for innovation. Teachers need to experiment, to explore, and to innovate, and administration needs to be receptive to the results. A formal and rationalized administrative approach is not inherently permissive of this. 1.4

The French system of education, confronted with these challenges to its traditional structure, must bring about the necessary changes to bring France abreast of the needs of today--the students have demanded it, the economy demands it. 
1. H. Schelsky, "Technical Change and Educational Consequences," Education, Economy, and Society, ed. A. H. Halsey, Jean Floud, and C. Arnold Anderson (New York: The Free Press of Glencoe, Inc., 1961), p. 31.

2. Ibid., p. 31 .

3. Ibid., p. 35 .

4. Jean-Jacques Servan-Schrieber, "The American Challenge," trans. Ronald Steel, Harper's Magazine, (July, 1968), p. 32.

5. Ot to Feinstein, unpublished manuscript, "Economics of Higher Education: Quality and Personalism," X-2.

6. W. R. Fraser, "Education and Society in Modern France," Comparative Perspectives on Education, ed. Robert J. Havighurst, (Boston: Little, Brown and Company, 1968), p. 16.

7. Robert Ulich, The Education of Nations (Cambridge, Massachusetts: Harvard University Press, 1961), p. 169.

8. Feinstein, $\mathrm{X}-10$.

9. See "Que Pensent Les Etudiants De La Formation Sociologique Actuelle?" Aspects De La Sociologie Francaise, ed. Paul-Henry Chombart de Lauwe, (Paris: Les Editions Ouvrieres, 1966), pp. 198-199.

10. Frederic Gaussen and Guy Herzlich, "Paris a été l.e theatre de violentes manefestations d'étudiants," Le Monde, Selection Hebdomadaire, May 2-8, 1968, p. 7.

11. Ibid., p. 7.

12. Jean Block-Miche1, "France--A New Kind of Rebellion," Dissent, July-August, 1968, p. 290.

13. Michel Vermot-Gauchy, "L'education nationale dans 1 a France de demain," Monaco, 1965, p. 14.

14. John Forster, "The New Zealand Case," On Education--Sociological Perspectives, ed. Donald A. Hansen and Joel E. Gerstl, (New York: John Wiley \& Sons, Inc., 1967), p. 269. See also Paul Ricoeur, "La relation 'enseignant-enseigné," " Le Monde, Selection Hebdomadaire, June 20-26, 1968, p. 6; and Robert Escarpit, "Demain 1'université," Le Monde, Selection Hebdomadaire, May 22-June 5, 1968, p. 7. 